DOI: 10.17707/AgricultForest.61.1.32

\author{
Julijana TRIFKOVIĆ, \\ Đorđe SAVIĆ, Stoja JOTANOVIĆ, Marinko VEKIĆ ${ }^{1}$
}

\title{
ORGANIC MILK INGREDIENTS AS AN INDICATOR OF ENERGY STATUS OF COWS WITH DIFFERENT MILK PRODUCTION DURING THE FIRST 100 DAYS OF LACTATION
}

\begin{abstract}
The aim of the study was to evaluate energy status of cows with different milk production during the first 100 days of lactation, based on the concentration of organic milk ingredients and ratio of urea and protein. The study included a total of 174 Holstein cows, divided into three groups based on daily milk yield (group $\mathrm{A}, \mathrm{n}=15$, bellow 20 litters, group $\mathrm{B}, \mathrm{n}=64$, from 20 to 30 litters, group $\mathrm{C}$, $\mathrm{n}=95$, above 30 litters). All cows were kept under usual farm conditions and fed diets adjusted to production category and period of the year. The concentration of milk fat declined with increasing daily milk production, while the concentration of urea had opposite trend. The concentrations of lactose and protein were the highest in the group B, while groups A and C had similar values. Statistically significant differences between all tested groups were found in concentrations of milk fat ( $4.28 \pm 0.56$ versus $3.95 \pm 0.51$ and $3.62 \pm 0.47 \%$, respectively), urea ( $2.81 \pm 0.32$ versus $3.03 \pm 0.52$, and $3.76 \pm 0.56 \mathrm{mmol} / 1$, respectively), as well as the values of the concentrations of lactose and proteins between groups $\mathrm{B}$ and $\mathrm{C}$ $(4.79 \pm 0.14$ versus $4.73 \pm 0.13$, and $3.10 \pm 0.21$ versus $3.01 \pm 0.24 \%)$. The distribution of values for the tested parameters within charts showing the relationships between urea and protein indicates a more or less pronounced energy deficit and the deficit or relative surplus of dietary protein in most of the cattle, which adversely affects their daily milk production and health.
\end{abstract}

Key words: cow, milk, energy status

\section{INTRODUCTION}

Intensive genetic selection and improvement of nutrition and care over the past several decades have led to a significant increase in milk yield per cow. This was contributed by serial of studies aimed to discovering new physiological mechanisms that influence the efficiency in milk production, as well as defining the influence of many factors on the expression of genetic potential in cows of high milk production. These studies pointed to the increased incidence of health

\footnotetext{
1 Julijana TRIFKOVIĆ (corresponding author: trifkovicj@yahoo.com), University of East Sarajevo, Faculty of Agriculture, Bosnia and Herzegovina; Đorđe SAVIĆ, Stoja JOTANOVIĆ, Marinko VEKIĆ, University of Banja Luka, Faculty of Agriculture, Bosnia and Herzegovina
}

Paper presented at the $5^{\text {th }}$ International Scientific Agricultural Symposium "AGROSYM 2014".

Notes: The authors declare that they have no conflicts of interest. Authorship Form signed online. 
problems in cows, especially metabolic disturbances, based on impossibility of harmonizing the need for maintaining the life and high milk production with intake of energy and nutrients through diet. The occurrence of metabolic disorders, together with mastitis and reproduction disorders is the main limiting factor for further improvement of milk production in the world, including Republic of Srpska. Import of high genetic potential dairy cows during the last two decades did not provide satisfying results in increasing milk production in Republic of Srpska, primarily because it had not been accompanied by corresponding changes in feeding management, which resulted in earlier culling and insufficient use of their genetic potential.

Inadequate feeding management in high-yielding dairy cows often result in negative energy balance (NEB), especially noticeable at the beginning of lactation, when the increase in daily food intake is not always able to follow the increase in daily milk production (Baumgard et al., 2006). Therefore, mobilization of the body's energy reserves occurs, primarily body fat depots, known as lipomobilization. Strong homeorhetic control of lactation, similar to pregnancy, cause steady increase in daily milk production during the first weeks of lactation, regardless of food intake (Bauman and Currie, 1980). It will deepen the NEB, so energy metabolism disorders and other accompanied disorders (abomasal displacement, laminitis, sub-acute rumen acidosis, reproductive disorders, and locomotory diseases) are practically the most abundant group health disorders in high-yielding dairy cows (Geishauser et al., 1997, Čejna and Chládek, 2005, Podpečan et al., 2007, 2013). It is important to emphasize that the main factor that determines the intensity of the NEB is the coherence of nutrient intake through diet and load of cow metabolism caused by the daily milk yield. In the other words, the intensity of the NEB is regularly higher in cows with higher milk yield, which is manifested through a longer period of lipomobilization (NRC, 2001) and by the extension in achieving energy balance, (Šamanc et al., 2005). Prolonged duration of NEB have negative impact on the extending the service period and calving interval (Biderman, 2007, Biderman et al., 2007), as well as the production of milk (Stokes et al., 2000).

The basis for the correction of any health disorders, including disorders of energy metabolism lies in timely and reliable diagnosis. In the diagnosis of health disorders and energy metabolism of high-yielding dairy cows a variety of methods has been used (metabolic profiles, analysis of metabolically active hormones, body condition score, ration analysis and other) (Tavel et al., 2005), but particularly interesting method for our conditions is estimating of energy status by using the concentrations and ratio of organic milk ingredients. A more detailed description of this method and results of the assessment are given by Šamanc et al. (2006), Orešnik (2009), Kirovski et al (2011, 2012, 2013), as well as in our previous papers (Savic et al., 2010, 2011, 2012, 2013). There are more allegations about this method in the literature (Kampl and Stolla, 1995, Jonker and Kohn, 2001 Babnik and Podgoršek, 2002, Eicher, 2004, Marenjak et al., 2004, Kampl, 2005, Horvat et al., 2007, 2009, Paura et al., 2012), which 
confirms its usability in commercial dairy farms. However, most authors stated that for assessing the results is necessary to collect the data on the amount of daily milk yield, composition and consumption of ration, and stage of lactation, in order to make valid conclusions and make recommendations for the correction of the ration.

Given all above mentioned, especially connection between the amount of daily milk yield and the cow energy status, the aim of this study is to make assessment of energy status of cows with different milk yield during the first 100 days of lactation, based on the concentration and ratio of organic milk constituents.

\section{MATERIALS AND METHODS}

The study was conducted on commercial dairy farm, during the summer diet period, mainly based on fresh green mass. In a total of 174 Holstein cows, 107 of them were in the first $(n=84), 61$ in the second, and 6 cows in the third or more lactations. The study included animals from 10 to 100 days of lactation, divided into groups based on the amount of daily milk production. The first group (group $\mathrm{A}, \mathrm{n}=15$ ) consisted of animals with a daily production of milk up to 20 litters, second (group $\mathrm{B}, \mathrm{n}=64$ ) animals with a daily production ranging from 20 to 30 litters of milk, and the third (group $\mathrm{C}, \mathrm{n}=95$ ) animals producing more than 30 litters of milk per day.

The cows were kept in outdoor system and fed with ration adjusted to the needs of production and period of the year. Milk samples were collected during regular milking, and concentration of milk fat, protein, lactose and urea were measured. Data on daily milk yield of the surveyed cows were taken from the records of the farm. The concentrations of milk organic ingredients were determined on 150 Bentley Milk Infrared Analyser, except the concentration of the urea, which was determined on a Bentley Chemspec150 for Milk Urea Analyser. Ratios of the urea and protein concentration in different groups of cows are presented graphically. The results were processed by descriptive statistics and presented in tables. The statistical significance of differences between the examined parameters was determined by t-test at the level of $p<0.05$ and $\mathrm{p}<0.01$.

\section{RESULTS AND DISCUSSION}

Average values of the examined parameters, as well as the statistical significance of differences between different groups of cows are given in Tab. 1.

The data presented in Table 1 indicate a statistically significant difference in all of examined parameters between different groups of cows. The average value of the concentration of the organic milk ingredients, for all of three groups of cows were within physiological limits, with the exception of the protein concentrations in the group A, which is slightly below the lower physiological limit typical for the given breed and category of the animal. Presented data are in 
accordance with the statements of other authors (Šamanc et al., 2006, Horvat et al., 2009, Savic et al., 2010, 2011, 2012, 2013, Kirovski et al., 2012).

Table 1 Daily milk yield and concentration of organic milk ingredients $(X \pm S D)$ of cows with different milk yield

\begin{tabular}{|c|c|c|c|c|c|}
\hline \multirow{2}{*}{ Parameter } & \multicolumn{3}{|c|}{ Group } & $\begin{array}{c}\text { Statistical significance } \\
\text { of differences }\end{array}$ \\
\cline { 2 - 6 } & $\begin{array}{c}\mathbf{A} \\
(\mathbf{n = 1 5})\end{array}$ & $\begin{array}{c}\mathbf{B} \\
(\mathbf{n = 6 4})\end{array}$ & $\begin{array}{c}\mathbf{C} \\
(\mathbf{n = 9 5})\end{array}$ & $\mathbf{P}<\mathbf{0 , 0 5}$ & $\mathbf{P}<\mathbf{0 , 0 1}$ \\
\hline $\begin{array}{c}\text { Milk yield } \\
(l)\end{array}$ & $16,68 \pm 2,11$ & $26,14 \pm 2,83$ & $36,33 \pm 5,07$ & & A:B, A:C, B:C \\
\hline Milk fat (\%) & $4,28 \pm 0,56$ & $3,95 \pm 0,51$ & $3,62 \pm 0,47$ & A:B & A:C, B:C \\
\hline $\begin{array}{c}\text { Proteins } \\
(\%)\end{array}$ & $2,99 \pm 0,35$ & $3,10 \pm 0,21$ & $3,01 \pm 0,24$ & & B:C \\
\hline Lactose(\%) & $4,74 \pm 0,11$ & $4,79 \pm 0,14$ & $4,73 \pm 0,13$ & & B:C \\
\hline $\begin{array}{c}\text { Urea } \\
\text { (mmol/l) })\end{array}$ & $2,81 \pm 0,32$ & $3,03 \pm 0,52$ & $3,76 \pm 0,56$ & A:B & A:C, B:C \\
\hline
\end{tabular}

Concentration of the milk fat had an opposite trend compared to the amount of daily milk production, which is the expected result, since it is known that the Holstein breed cows give more milk yield with a lower fat content compared to Simmental cows (Kirovski et al., 2012). In group A, the concentration of milk fat was above the upper limit of the physiological range, or at the lower limit values that point to the process of lipomobilization. Along with the effect of daily milk yield on the milk fat content, this finding is most likely due to the fact that cows in group A were in milk shorter compared to the other two groups of cows (average of 36.13 days vs. 44.86 days in group B, and 52.84 days in group $\mathrm{C}$ ). In all three groups of cows slightly higher average concentration of milk fat has been observed, compared to the range of 3.2 to 3.6\% cited by Kirovski et al. (2012). This is probably a result of the influence of individual values for cows that are at the very beginning of lactation and in which there lipomobilization exists on the total average group value.

Protein concentration in milk all three groups of cows varied within a relatively narrow range, indicated by the coefficients of variation ranging from $6.91 \%$ in group B to $11.67 \%$ in group A. However, in all of three groups of cows is evident that the protein concentration is on the lower limit of the interval 3.06 to $3.2 \%$, given by Kirovski et al. (2012). The average values of the protein concentration obtained in this study approximate the values from 30.17 to $30.33 \mathrm{~g} / \mathrm{L}$, obtained by Savic et al. $(2010,2011)$. In generally, decreased protein content is most probably a result of insufficient supply of energy via ration, so the rumen micro flora was unable to bind fast enough ammonia formed by decomposition of the proteins from the ration and incorporate it into its own proteins, which would later be used as a source of amino acids for the milk protein synthesis of. 
The disbalance between energy and protein content in the diet of the surveyed group of cows is also indicated by the content of urea in milk, which rises with increasing of daily milk yield.

This trend of average values of milk urea points to the fact that the increase of daily milk yield reduces the utilization of proteins. It also increases the amount of ammonia that is being resorbed through the mucous membrane of the rumen and detoxicated by the hepatic conversion to urea, which then passes into the milk. In other words, because of inadequate ratio of energy and protein in the diet, cows with higher milk yield insufficiently utilize the protein component of the ration, thus producing an economic burden, while at the same time become more sensitive to health disorders.

The average concentration of lactose in all groups varied within narrow limits, which is indicated by the low coefficients of variation, ranging from 2.30 to $2.94 \%$. A narrow interval of average concentrations of lactose, with the known fact that the milk lactose is an osmotic active ingredient and binds water which directly affects the daily milk yield, indicates the strong homeorhetic control of its synthesis and secretion, which has been confirmed in previous studies (Savic et al., 2013).

Considering that the shown values of concentration and the relationship of organic milk ingredients represent the average of a given group of cows, we have shown data for milk fat : protein ratio as well as urea: protein ratio graphically, to have insight into the overall state of supply of energy and protein at the group level.

Ratio of urea and protein in milk of cows with different milk yield are shown in Figure 1, 2 and 3.

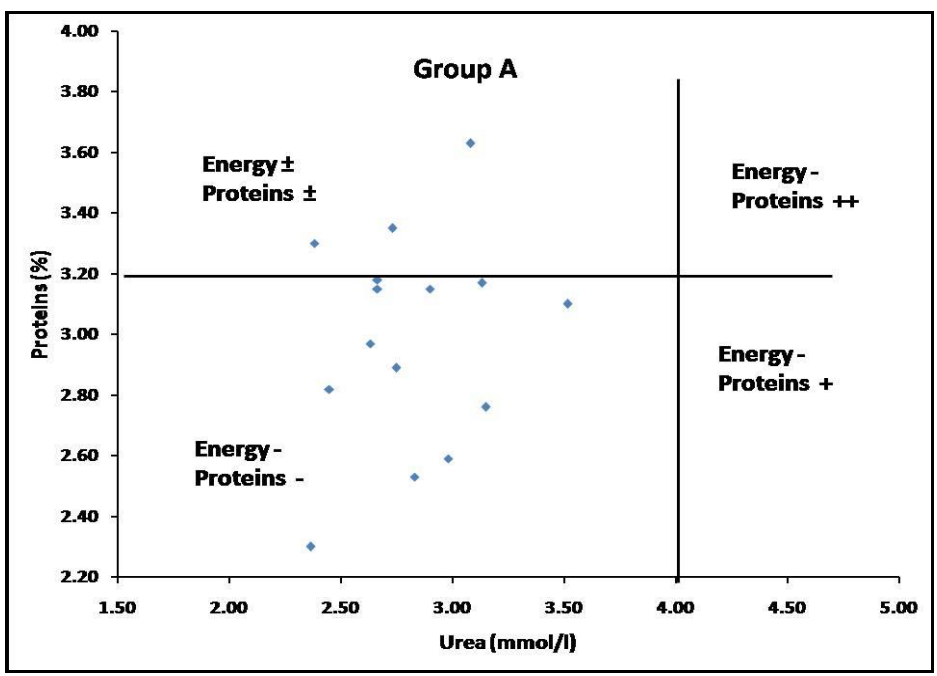

Figure 1. The ratio of proteins and urea milk concentrations in cows of group A 


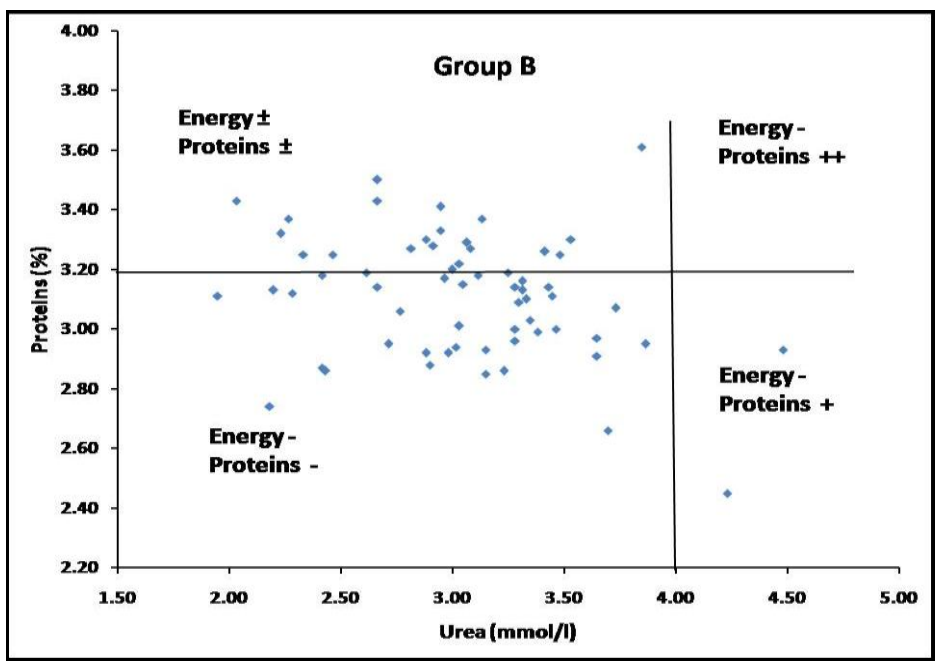

Figure 2. The ratio of proteins and urea milk concentrations in cows of group B

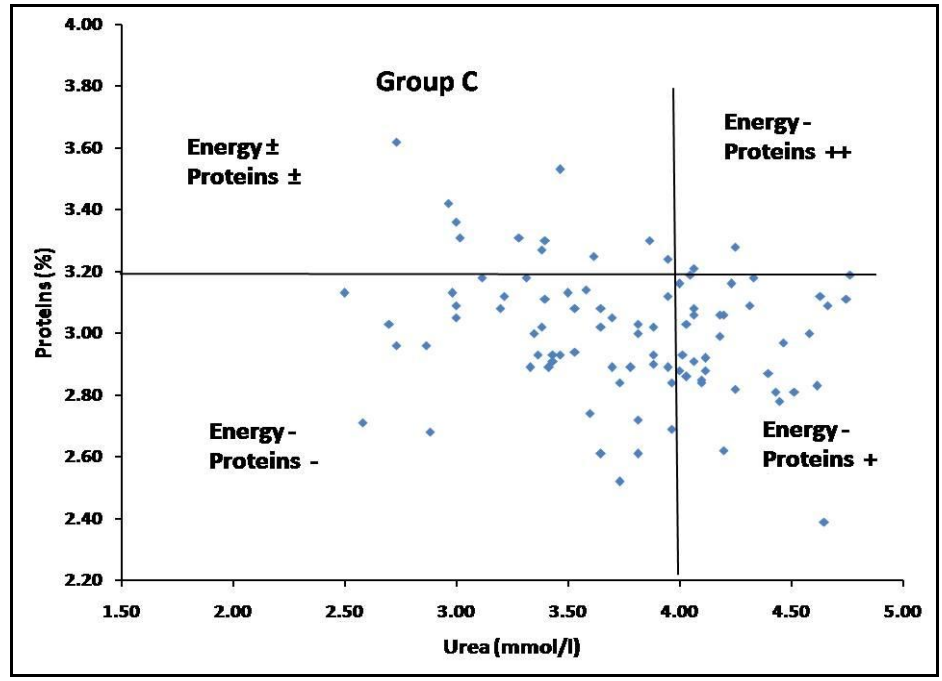

Figure 3. The ratio of proteins and urea milk concentrations in cows of group $\mathrm{C}$

Kirovski et al. (2012) reported that the average physiological concentration of urea in Holstein cows ranging from 2.0 to $6.0 \mathrm{mmol} / \mathrm{l}$, and, as urea concentration limit that will lead to metabolic disorders, values above $4.0 \mathrm{mmol} / \mathrm{l}$ are taken. The excess of ammonia from the rumen, produced when microorganisms are insufficiently supplied with energy, is being transported through the bloodstream to the liver where it is converted to the urea (Konjačić et al., 2010). From the above figures is noticeable that most of the cows in our research are in the lower left quadrant, indicating diet deficient in energy and protein (absolute deficit). This result is a relatively common phenomenon during 
the summer period, considering that the fresh green mass contains a small amount of energy and a high protein content, which limits the usability of proteins from the ration. The results obtained in this study are in accordance with the results obtained by Šmanc et al. (2006), Horvat et al. (2009) and Savic et al. (2010, 2011, 2012, 2013). In groups B and C a small number of cows that are in the upper left quadrant is evident, indicating an adequate supply of energy and protein. This finding is probably a result of the lactation period in which samples of milk are taken, but also because of the individual variations in capacity of energy and protein utilization of from ration. Also, a certain number of cows that are in the upper and lower right quadrant of the chart is evident; indicating more or less expressed relative excess of protein. This situation adversely affects milk production, and elevated amount of ammonia (unutilized by rumen microorganisms due to the energy deficient) is a potential health risk to the animals, which is particularly prevalent in the cattle group $\mathrm{C}$.

\section{CONCLUSION}

Understanding the functioning of the metabolism in high yielding cows is the starting point for the correct interpretation of their nutritional needs in order to efficiently exploit their genetic potential for milk production, while preserving good health and reproductive characteristics. The results of this study are a contribution to this issue, through the practical application of knowledge of the physiological processes of food digestion, utilisation of certain nutrients as well as the synthesis and secretion of milk in assessing satisfying nutritional and energy requirements of cows, but also indicating the general health status of the cows.

In the long term, the inadequate supply of cows in energy and protein, according to the results of this study, will have a negative effect on the expression of genetic potential for milk production, reproductive performance of cows, and certainly the health of the herd. Analysis of individual results within the surveyed groups of cows indicates a high prevalence of subclinical health disorders, which can negatively affect the health and productive life of cows with economically burden of the farms. Differences in concentrations of organic milk contents between different groups of cows, as well as their energy status indicates the need for grouping cows according to daily milk yield and the stage of lactation, in order to make a quality adjustment of ration in accordance to their needs and enable them to the fully exploit of their genetic potential.

In addition, the results of this study indicate the significant potential of the method applied in monitoring the metabolic status of the cow and the early detection of animals susceptible to the occurrence of health disorders, enabling timely and effective response of the veterinary service. By monitoring data in this way, it is possible to achieve a good insight into the feeding management of cows on this farm, and analyse the effects of correction of the ration, which would have a positive impact on the economic impact of the farming business in the long term. 


\section{REFERENCES}

Babnik, D., Podgoršek, P. (2002): Sestava mleka kot pokazatelj prehranskih napak pri kravah molznicah. V: Zbornik predavanj 11. posvetovanja o prehrani domacih živali »Zadravcevi - Erjavcevi dnevi«, Radenci, 11-12 nov. 2002. Pen A. (ur.). Murska Sobota, Kmetijsko gozdarska zbornica Slovenije, Kmetijsko gozdarski zavod: 181196

Bauman, D.E., Currie, W.B. (1980): Partitioning of nutrients during pregnancy and lactation: a rewiew of mechanisms involving homeostasis and homeorhesis. J. Dairy Sci., 63, 1514-1529.

Baumgard, L.H., Odens, L.J., Kay, J.K., Rhoads, R.P., Van Baale, M.J., Collier, R.J. (2006):Does negative energy balance (NEBAL) limit milk synthesis in early lactation? Proc South-west Nutr Conf; 181-87.

Biderman, A., Verbič, J., Logar, B. (2007): Povezava med razmerjem med maščobami in beljakovinami $\mathrm{v}$ mleku $\mathrm{v}$ obdobju po telitvi in dobo med telitvama pri kravah molznicah, Zbornik predavanj 16. mednarodno znanstveno posvetovanje o prehrani domačih živali "Zadravčevi-Erjavčevi dnevi", Radenci, 8-9, novembar, 2007, Murska Sobota, Kmetijsko gozdarska zbornica Slovenije, Kmetijsko gozdarski zavod, 245-254.

Biderman, Andreja (2007): Vpliv mlečnosti in razmerja med maščobami in beljakovinami v mleku na dobo med telitvama pri kravah molznicah. Diplomsko delo, Univerza v Ljubljani, Biotehniška fakulteta, Oddelek za zootehniko.

Čejna, V., Chládek, G. (2005): The importance of monitoring changes in milk fat to protein ratio in Holstein cows during lactation, Journal of Central Europan Agriculture, 6, 539-545.

Eicher, R. (2004): Evaluation of metabolic and nutritional situation in dairy herds : Diagnostic use of milk components, In: Proceedings of WBC congress, Quebec 11-16 July, Canada.

Geishauser, T., Leslie, K., Duffield, T., Edge, V. (1997): Fat/protein ratio in first DHI test milk as test for displaced abomasum in dairy cows, J. Vet. Med., A 44, 265-270.

Horvat, J., Kirovski, Danijela, Šamanc, H., Dimitrijević, B., Kiškarolj, F., Bečkei, Ž., Kilibarda, Nataša (2009): Procena energetskog statusa krava sa područja Subotice određivanjem organskih sastojaka mleka, Zbornik radova XI regionalnog savetovanja iz kliničke patologije i terapije životinja „Clinica Veterinaria 2009“, Subotica, 19.-21. jun, 2009, 99-101.

Horvat, J., Šamanc, H., Kirovski, Danijela, Katić, Vera (2007): Zdravstveni poremećaji visokomlečnih krava u ranoj fazi laktacije i uticaj na higijensku ispravnost sirovog mleka, Veterinarski specijalistički institut Subotica

Kampl, B. (2005): Pokazatelji energetskog deficita mlečnih krava u mleku i njihovo korišćenje u programu zdravstvene preventive i intenziviranja proizvodnje $\mathrm{i}$ reprodukcije, Zbornik radova IV simpozijuma „Ishrana, reprodukcija i zaštita zdravlja goveda - Etiopatogeneza i dijagnostika poremećaja metabolizma reprodukcije goveda“", Subotica, 27. septembar - 01. oktobar, 2005., 261-267.

Kampl, B., Stolla R. (1995): Pokazatelji energetskog deficita mliječnih krava u mlijeku i njihovo korištenje u programu zdravstvene preventive i intenziviranja proizvodnje i reprodukcije. Praxis veterinaria, 42(3): 189-97.

Kirovski Danijela, Šamanc, H., Vujanac, I., Prodanović, R., Sladojević, Ž., Savić, Đ. (2013): Prediction of energy balance of early lactating dairy cows from milk composition measures at individual cow level, II International Symposium and XVIII Scientific Conference of Agronomists of Republic of Srpska, Trebinje, Bosnia and Herzegovina, March 26.-29., 2013, Book of Abstracts, 152. 
Kirovski, D., Šamanc, H., Vujanac, I., Prodanović, R., Sladojević, Ž. (2011): Evaluation of dairy cows energy status by biochemical analysis of organic components of milk, Proceedings of Days of veterinary medicine, 9-11 Septembar 2011, Ohrid, Macedonia

Kirovski, Danijela, Šamanc, H., Prodanović, R. (2012): Procena energetskog statusa krava na osnovu koncentracije masti, proteina i uree u mleku, Veter. glasnik, 66, 1-2, 97-110.

Konjačić M., Kelava N., Lukić S., Ivanković A., Prpić Z., Vnučec I., Ramljak J., Mijić P., (2010): Non-nutritional factors of milk urea concentration in Holestein cows from large dairy farms in Croatia. Mljekarstvo 60 (3), 166-174

Marenjak, T.S., Poljičak-Milas, N., Stojević, Z. (2004): Svrha određivanja koncenracije ureje u kravljem mlijeku. Praxis Veterinaria, 52(3): 233-41.

Mulligan, F., O'Grady, L., Rice, D., Doherty, D. (2006): Production disease of the transition cow: Body condition score and energy balance, Irish Veter. Journal, 59, 9, 505-510.

Orešnik, A. (2009): Uticaj ishrane na proizvodnju i sastav mleka. zdravstveno stanje i plodnost visokomlečnih krava, Zbornik radova XI regionalnog savetovanja iz kliničke patologije i terapije životinja „Clinica Veterinaria 2009“, Subotica, 19.-21. jun, 2009, 27-36.

Paura, Liga, Jonkus, Diana, Ruska, Diana (2012): Evaluation of the milk fat to protein ratio and fertility traits in Latvian brown nad Holstein dairy cows, Acta agriculturae Slovenica, Supplement 3, 155-159

Podpečan, O., Kosec, M., Cestnik, V., Čebulj-Kadunc, N., Mrkun, J. (2007): Impact of negative energy balance on production and fertility in Slovenian Brown-breed dairy cows, Acta Veterinaria, vol. 57, 1, 69-79.

Podpečan, O., Mrkun, J., Zrimšek, P. (2013): Assosiations between the fat to protein ration in milk, health status and reproductive performance in dairy cattle, Slovenian Veterinary Research, 50, 2, 57-66.

Savić, Đ., Kasagić, D., Jotanović, Stoja, Matarugić, D., Šarić, M., Mijatović, R. (2011): Procjena energetskog statusa krava u ranoj laktaciji na osnovu određivanja organskih sastojaka mlijeka, Agroznanje, vol. 12, 1, 67-74.

Savić, Đ., Matarugić, D., Delić, N., Kasagić, D., Stojanović, M. (2010): Određivanje organskih sastojaka mleka kao metoda ocene energetskog statusa mlečnih krava, Veterinarski glasnik, 64, 1-2, 21-32.

Savić, Đ., Stoja Jotanović, Danijela Kirovski, Vekić, M. (2013): Changes of concentration of organic milk ingredients and their ratios during different periods of standard lactation, II International Symposium and XVIII Scientific Conference of Agronomists of Republic of Srpska, Trebinje, Bosnia and Herzegovina, March 26.-29., 2013, Book of Abstracts, 355.

Savić, Đ., Stoja Jotanović, Vekić, M., Kasagić, D. (2012): Evaluation of cow energy status changes during early lactation based on concentrations of organic milk ingredients, I International Symposium and XVII Scientific Conference of Agronomists of Republic of Srpska, Trebinje, Bosnia and Herzegovina, March 19.-22., 2012, Book of Abstracts, 223.

Stokes S.R., Waldner D.N., Jordan E.R., Looper M.L. (2000) Managing milk composition: Evaluating herd potential. Texas agricultural extension service, The Texas A\&M University System, L-5387, 12. http://agpublications.tamu.edu/pubs/as/15387.pdf

Šamanc, H., Kirovski, Danijela, Dimitrijević, B., Vujanac, I., Damnjanović, Z., Polovina, M. (2006): Procena energetskog statusa krava u laktaciji određivanjem organskih sastojaka mleka, Veterinarski glasnik, 60, 5-6, 283-297.

Tavel, L., Kirchhofer, M., Doherr, M.G., Kaufmann, T., Eichner, R. (2005): Comparison of methods to evaluate energy supply in dairy herds, Dtsch. Tierärtzl, Wschr. 112, 443 448 . 